\title{
Prophetic Leadership Khulafaur Rosyidin
}

\author{
Yuni Masrifatin \\ STAI Miftahul Ula Nganjuk \\ yunimasrifatin@gmail.com
}

\begin{abstract}
Leadership is a mandate and therefore, in an Islamic system, one must not demand a position. Leaders have a very important position for community groups, nation and state. A community, nation and state will not advance, safe and directed if there is no leader. Leaders become the key to success in a community, leaders who are able to provide a sense of security, peace, and able to realize the wishes of their people, that is what is considered a successful leader. Successful leaders are leaders who are loved by those they lead, so their minds are always supported, their orders are always followed and the people defend them without being asked first. The leadership figure that approaches this explanation is the leadership of the Prophet and his companions (Khulafaur Rasyidin). Abu Bakr was chosen to be the caliph to replace leadership after the Messenger of Allah was a blessing in itself, and this kind of privilege was given to him by Allah. Basically the companions of the Prophet are people who will inherit Islamic da'wah / treatise for all mankind, as well as being a leader for themselves with their exemplary example and the Islamic faith in carrying out the shari'ah of Allah Almighty and His Rasul, both through the book of Allah and the sunnah of the Messenger of Allah. In this paper, it will be discussed how the leadership progress in the Khulafaur Rosyidin period, as long as a leader, the problems faced as well as the progress that has been achieved in fighting for and expanding the Islamic territory, so that Islam can be glorious at that time.
\end{abstract}

Keyword : Prophetic, Prophetic Leadership, Khulafaur Rosyidin

\section{INTRODUCTION}

Khilafah Rasyidah was a Muslim leader after the Prophet Muhammad died, namely during the reign of Abu Bakr, Umar bin Khattab, Uthman bin Affan and Ali bin Abi Talib, where the system of government that is applied is democratic governance. The Prophet Muhammad did not leave a will about who would succeed him as the political leader of the Muslims after his death. He seems to leave the matter to the Muslims themselves to determine it. For this reason, not long after he died; not to mention his body was buried, a number of Muhajirin and Ansar figures gathered at the town hall of the Bani Sa'idah, Medina.

They deliberate on who will be chosen as the leader. The deliberations went pretty tough because each party, both Muhajirin and Anshar, both felt entitled to become leaders of Muslims (Fachrurozi 2015). However, with the spirit of high ukhuwah Islamiyah, finally, Abu Bakr was elected. Apparently, Abu Bakr's religious zeal 
received high appreciation from Muslims, so that each party accepted and pledged allegiance (Susmihara 2015a).

Starting from the time of Abu Bakr until Ali was called the Rashidah Khilafah period. The caliphs were called al-Khulafa 'al-Rashidun, (the caliphs who received instructions). This period is characterized by the caliphs truly according to the example of the prophet (Friday 2014). After this period, Islamic government took the form of a kingdom. Power is inherited from generation to generation (Yusalia 2016). In addition, a caliph during the Rashidah caliphate, never acted alone when the state faced difficulties; They always consult with other dignitaries. Whereas the rulers afterwards often acted authoritatively (Ayief Fathurrahman 2018).

\section{RESULT AND DISCUSSION}

The period of Abu Bakr ra. (11-13 H / 632-634 AD)

Abu Bakr ash-Shiddiq (573 - 634 AD, caliph 632 - 634 AD) was born with the name Abdus Shams, "Abu Bakar" is a title given by the Muslim community to him (Rahmatullah 2014). His real name is 'Abdullah bin Abi Quhafah'. He got the title 'as-Shiddiq' after converting to Islam. The name before the Muslim is "Abdul Kaaba". His mother's name was "Salma Ummul Khair", the uncle's son "Abu Quhafah". Abu Bakr was the first Caliph of Islam after the death of the Prophet Muhammad. He is one of the higher-ups Mecca of the tribe Quraysh. After converting to Islam his name was changed by Muhammad to Abu Bakr. He was named Ash-Shiddiq which means a trusted one after he became the first person to acknowledge the events of Isra 'Mi'raj (Rahmatullah 2014).

He also was the person appointed by Muhammmad to accompany him to migrate to Yathrib. He is noted as one of Muhammad's most loyal and foremost Friends of protecting Muslims even against his own tribe. When Muhammad was very ill, Abu Bakr was the person appointed by him to succeed him Priest inside prayers Congregationalin the mosque Nabawi. This according to most scholars is an indication from the Prophet Muhammad that Abu Bakr was appointed as the successor to the leadership of Islam, while a small number of Muslims at the time, who later formed a Shiite political alliance, more refers to Ali bin Abi Talib because he is the family of the prophet. After a long period of debate finally through the joint decision of the Muslim community at that time, Abu Bakr was appointed as the first Muslim leader after Muhammad's death (Susmihara 2015b).

During the two years of Abu Bakr's leadership, Arab society under Islam experienced rapid progress in the social, cultural and law enforcement fields. During his leadership also, Abu Bakr managed to expand the Islamic territory to Persia, in part Arabian Peninsula to conquer parts of the empire Byzantine. Abu Bakr died at the age of 61 years in $634 \mathrm{AD}$ due to illness he experienced. Abu Bakr became a caliph for only two years. In $634 \mathrm{AD}$ he died. Such a short period of time was spent to solve domestic problems, especially the challenges caused by the 
Arab tribes who did not want to submit to the Madinah government after the death of the Prophet Muhammad. They assume that the agreement made with the Prophet Muhammad, was automatically canceled after the Prophet's death. Therefore they oppose Abu Bakr. Because of their stubbornness and opposition that could jeopardize religion and government, Abu Bakr solved this problem with the so-called Riddah War (war against apostasy). Khalid bin Al-Walid was the commander who contributed a lot in this Riddah War. It seems that the power exercised during the Caliph Abu Bakr, as in the time of the Prophet, was central; legislative, executive and judicial powers are centralized in the hands of the caliph. In addition to running the government, the Caliph also carried out the law established in the Qur'an and as-Sunnah. However, like the Prophet Muhammad, Abu Bakr always invited his great friends to deliberate.

It was only after completing the internal affairs of the war that Abu Bakr sent power outside Arabia. Khalid bin Walid was sent to Iraq and was able to conquer the territory of al-Hirah in 634 AD To Syria sent an expedition under the leadership of four commanders namely Abu Ubaidah ibnul Jarrah, Amr ibnul 'Ash, Yazid bin Abi Sufyan and Syurahbil bin Hasanah. Previously the troops were led by Usamah bin Zaid who was 18 years old. To strengthen this army, Khalid bin Walid was ordered to leave Iraq, and through the desert which was rarely traveled, he reached Syria.

As the leader of the Muslims after the Apostle, Abu Bakr was called the Caliph Rasulillah (Substitute of the Apostles) which in subsequent developments was called the Caliph only. The Caliph was a leader who was appointed after the Prophet's death to succeed him in continuing his duties as religious leader and head of government. Abu Bakr became a caliph for only two years. In 634 AD he died. This short period of time was spent to solve domestic problems, especially the challenges posed by the Arab tribes who did not want to submit to the Madinah government anymore. They consider that the agreement made with the Prophet Muhammad, was automatically canceled after the Prophet's death. Therefore they oppose Abu Bakr. Because of their stubbornness and opposition that could jeopardize religion and government, Abu Bakr solved this problem with the socalled Riddah War (war against apostasy). Khalid ibn Al-Walid was a general who contributed a lot in this Riddah War.

It seems that the power exercised during the Caliph Abu Bakr, as in the time of the Prophet, was central; legislative, executive and judicial powers are centralized in the hands of the caliph. In addition to running the government, the Caliph also carried out the law. However, like the Prophet Muhammad, Abu Bakr always invited his great friends to deliberate. It was only after completing the internal affairs of the war that Abu Bakr sent power outside Arabia. Khalid ibn Walid was sent to Iraq and was able to conquer al-Hirah in 634 AD. To Syria was sent an expedition under the leadership of four generals namely Abu Ubaidah, Amr ibn 
'Ash, Yazid ibn Abi Sufyan and Syurahbil. Previously the troops were led by Osama who was 18 years old (Saunders 2002).

To strengthen this army, Khalid ibn Walid was ordered to leave Iraq, and through the desert which was rarely traveled, he reached Syria. One of the monumental things in the era of Abu Bakr ra was the collection of Al-Qur'an Manuscripts from other friends, led by Zaid bin Thabit ra (Fitri Sukmawati 2015).

\section{The period of Umar Ibn Khatab ra. (13-23 H / 634-644 AD)}

Abu Bakr died, while the vanguard of the Islamic forces was threatening Palestine, Iraq and the kingdom of Hirah. He was replaced by his "right hand", Umar ibn Khattab. When Abu Bakr became ill and felt his end was near, he consulted with the leaders of friends, then appointed Umar as his successor with a view to preventing the possibility of disputes and divisions among Muslims. The wisdom of Abu Bakr turned out to be accepted by the people who immediately joined in the oath of allegiance to Umar. Umar called himself the Caliph Rasulillah (successor of the Prophet). He also introduced the term Amir al-Mu'minin (Commander of the believers).

Umar bin Khattab , became the caliph 634 - 644 AD is the second caliph in Islamic history. Umar's appointment was not based on consensus but based on the will left by Abu Bakr. This did not cause significant contradictions among Muslims at that time because Muslims were very familiar with Umar as the person who was the closest and most faithful in defending the teachings of Islam. Only a handful of people, who later became Shiite groups, who still maintain that Ali should be the caliph. Umar ruled for ten years from 634 to 644.

When Abu Bakr became ill and felt his end was near, he consulted with the leaders of friends, then appointed Umar bin Khatthab as his successor with a view to preventing possible disputes and disunity among Muslims. The wisdom of Abu Bakr turned out to be accepted by the people who immediately joined in the oath of allegiance to Umar. Umar called himself the Caliph Rasulillah (successor of the Prophet). He also introduced the term Amir al-Mu'minin (high-ranking believers). In the era of Umar the first wave of expansion (expansion of power) occurred; Syria's capital, Damascus, fell in 635 AD and a year later, after the Byzantine army was defeated at the Battle of Yarmuk, the whole area of Syria fell under Islamic rule. By using Syria as a base, expansion continued to Egypt under the leadership of 'Amr ibn' Ash and to Iraq under the leadership of Sa'ad ibn Abi Waqqash. Alexandria, the capital of Egypt, was conquered in 641 AD Thus, Egypt fell under Islamic rule. Al-Qadisiyah, a city near Hirah in Iraq, fell in 637 AD From there the attack continued on the Persian capital, al-Madain which fell that same year. In 641 AD, Mosul could be controlled. Thus, during Umar's leadership, the Islamic territories covered the Arabian Peninsula, Palestine, Syria, most of Persia, and Egypt. 
Because the expansion of the area happened quickly, Umar immediately set up the state administration by copying the administration that had developed, especially in Persia. Government administration is organized into eight provincial regions: Makkah, Medina, Syria, Jazirah Basrah, Kufa, Palestine, and Egypt. Several departments deemed necessary to be established. At the time, the system of payment of salaries and land taxes was arranged and put in order. The court was established in order to separate the judiciary from the executive. To maintain security and order, a police department is formed. Likewise, the public works department. Umar also founded Bait al-Mal, forged currency, and created a year of hijrah. One of the monumental things in the Sayidina Umar ra era was the tarawih prayer. The following is one of its history, which has become the grip of Muslims throughout the world until today[1].

Narrated by Yazid Ibn Khusayfah from Sâib Ibn Yazîd that all people do the 20 rak'ah tarawih prayers during the month of Ramadan during the caliph Umar Ibn Khatab ra. Hold tightly my sunnah and sunnah khulafaurrasyidin. Umar reigned for ten years (13-23 H / 634-644 AD). His term of office ended in death. He was killed by a slave from Persia named Abu Lu'lu'ah. To determine his successor, Umar did not take the path taken by Abu Bakr. He appointed six friends and asked them to choose one of them to be a caliph. The six people are Usman, Ali, Talha, Zubair, Sa'ad ibn Abi Waqqash, Abdurrahman ibn 'Awf. After Umar's death, the team deliberated and succeeded in appointing Uthman as caliph, through rather fierce competition with Ali ibn Abi Talib.

Umar ruled for ten years (13-23 H / 634-644 AD). His term of office ended in death. He was killed by a slave The Persians named Abu Lulu'ah were religious Zoroastrianism (Majusi). To determine his successor, Umar did not take the path taken by Abu Bakr. He appointed six friends and asked them to choose one of them to be a caliph. The six people are Usman, Ali, Talha, Zubair, Sa'ad bin Abi Waqqash, Abdurrahman bin 'Awf. After Umar's death, the team deliberated and successfully appointed Uthman as caliph, through a rather rigorous process with Ali bin Abi Talib (Radieah 2013).

\section{The period of Uthman Ibn 'Afan ra. (23-35 H / 644-655 AD)}

Uthman bin Affan was born in 573 AD into a family of the Quraysh tribe of the Umayyads. He was 6 years younger than the Prophet Muhammad. His ancestors united with the Prophet Muhammad in the 5th generation. Before entering Islam he was called Abu Amr. He was called Dzunnurain, because he married the two daughters of the Prophet (being caliph 644-655 AD) was the 3rd caliph in Islamic history. Umar bin Khattab could not decide how best to determine the successor caliph. Immediately after the event of his stabbing by Fairuz, a Persian majus, Umar considered not choosing a successor as the Prophet did. But Umar also thought of leaving a will like Abu Bakr did. As a way out, Umar appointed six 
Companions as the Formation Council in charge of electing the new Caliph. The six people are Abdurrahman bin Awf, Saad bin Abi Waqash, Talha bin Ubaidillah, Zubayr ibn Awwam, Uthman ibn Affan and Ali ibn Abi Talib.

During the reigns of Uthman, Armenia, Tunisia, Cyprus, Rhodes, and the remaining parts of Persia, Transoxania and Tabaristan were captured. The first expansion of Islam stopped here. The Usman government lasted for 12 years, in the last half of the caliphate there was a feeling of dissatisfaction and disappointment among Muslims towards him. Uthman's leadership was very different from Umar's leadership. This is due to slander and incitement from Abdullah bin Saba 'AlYamani, one of the Jews who pretended to convert to Islam. Ibn Saba 'was fond of moving from one place to another to spread slander to Muslims who were new to Islam. Finally in 35 H / 655 AD, Uthman was killed by the rebels consisting of people who were successfully instigated by Abdullah bin Saba '(Nurmala Rahmawati, Sugiyanto 2015).

One of the factors that caused many people to prejudice against Uthman's leadership was his policy of raising families in high positions. The most important of which is Marwan bin Hakam Rahimahullah. It was he who basically assumed by these people who ran the government, while Uthman only held the title of Caliph. After many members of his family sat in important positions, Usman was like a puppet before his relatives. He could not do much and was too weak towards his family. He is also not strict with subordinates' mistakes. The wealth of the country, by relatives distributed without control by Uthman himself. It was all due to the slander that was spread by Abdullah bin Saba ', even though Uthman was noted as the most credited with building dams to keep the flow of large floods and arrange the distribution of water to the cities. He also built roads, bridges, mosques and expanded the Prophet's mosque in Medina.

However, it does not mean that in his time there were no important activities. Usman was instrumental in building dams to maintain the flow of large floods and regulate the distribution of water to the cities. He also built roads, bridges, mosques and expanded the Prophet's mosque in Medina. The writing of the Koran was carried out again during the time of Uthman, may Allah be pleased with him. This happened in the year $25 \mathbf{A H}$. And the Qur'an that we hold today is the Uthmanic Manuscripts.

\section{The period of Ali Ibn Abi Talib kwh. (35-40 H / 655-660 AD)}

After Uthman's death, the community took lots of allegiance to Ali ibn Abi Talib as caliph. Ali ruled for only six years. During his reign, he faced various upheavals. There was not a single period in his government that could be said to be stable. After occupying the post of caliph, Ali fired the governors appointed by Uthman. He was convinced that the uprisings were due to their negligence. He also withdrew the land that was given by Uthman to the population by surrendering 
the proceeds of his income to the state, and re-used the annual tax distribution system among Muslims as had been applied by Umar.

Ali bin Abi Talib Ali was born in the city of Mecca, in the Hejaz region of the Arabian Peninsula about 10 years before Muhammad's prophethood. His father was: Abu Talib, uncle of the Holy Prophet, bin Abdul Muttalib, bin Hashim, bin Abdi Manaf, bin Qushayy. His mother was: Fatima bint Asad, bin Hashim, bin Abdi Manaf. Before the advent of Islam, the Hasyim family was known as a noble, loving family, and the holder of community leadership. Since childhood, Ali RA was known as a smart and brave child. Ali RA followed the Prophet SAW since he was 6 years old. He was also included in the group that first recognized the prophethood of Muhammad. He is known as a brave and simple figure (zuhud). His courage he showed in his ability to replace the position of the prophet in bed when the Prophet was going to migrate.

At that time the infidels had surrounded the house of the Prophet, but Ali (RA) was not afraid in the slightest. Ali proposed to one of the children of the Prophet, Fatimah Az-zahra. His children are: Hasan, Hussein, Zainab, Umm Kulthum, from Fatima bint Rasulullah SAW. A wife who was never treated badly by Ali ra in his life. Even Ali always remembered him after his death. He also had several children with his other wives, whom he married after the death of Fatima ra Both the wife of a free woman and a slave. Namely: Muhsin, Muhammad al Akbar, Abdullah al Akbar, Abu Bakr, Abbas, Uthman, Ja'far, Abdullah al Ashgar, Muhammad al Ashghar, Yahya, Aun, Umar, Muhammad al Awsath, Um Hani, Maimunah, Rahmlah ash Shugra, Zainab ash Shugra, Umm Kaltsum ash Shugra, Fatima, Umamah, Khadijah, Umm al Karam, Umm Salmah, Umm Ja'far, Jumanah, and Taqiyyah.

His courage was also shown to defend the banner of Islam. In the Battle of Badr, where there were only a few Muslim troops, the infidels who attacked multiplied in number. Ali RA became the encouragement of the Muslims, so they won. Because of the difficulty of facing multiple opponents, then when they won, the Islamic fighters were greeted with amazement and given the title "Ahlul Badar". Ali RA is also famous for his "dzulfikar" sword. In the battle of Uhud, Ali protected the Prophet (PBUH) who was then pinched until his teeth were even chipped and blood flowed everywhere. Shouts of Takbir from Ali reinforced the fighting spirit of the Companions, especially after seeing Rasulullah in critical condition. During the war the Prophet (SAS) lost many of his best friends, the Ahlul-Badr including his uncle Hamzah, the lion of the desert. However, Allah SWT replaced him by converting to Islam, the Commander of the Uhud war, Khalid bin Walid.

Khalid made a major contribution to the struggle of Islam until the end of his life. It was in this Uhud war that Ali RA saw the simplicity of the figure of Fatimah bint Muhammad SAW. Fatimah participated in the war and washed the wounds of her father and Ali RA, along with swords and bloodstained clothing. In the war of Khandak. War which is also counted crucial. back to being a hero, after only he was 
the only friend who 'dared to go' to challenge the challenge of an enemy known to be the most formidable champion, 'Amr bin Abdi Wud Ali fought one on one. Ali with his "dzulfikar" sword managed to slash 'Amr so that it was split into two. While in the Khaibar war, where the Jews violated the Huaibiah agreement and fought the Muslims, Ali managed to break through the fortress of Khaibar which was very sturdy and destroyed the defenses of the Jews.

The entire battle of the Prophet was followed by Ali, except for one in the Tabuk War. The Prophet asked him to stay in Mecca to maintain the stability of the region. Because the Messenger of Allah knew, there was a foul attempt by the munafiqs to weaken Mecca from within when the Prophet left to lead the Tabuk war. After the Prophet's death. He prefers solitude, struggling with knowledge, teach Islam to his students. During this time, Ali later honed himself into a thinker. His courage and courage that many admired had turned into someone who was synonymous with science. Ali was inspired by the words of the late Rasulullah, "if I am a city of knowledge, then Ali is the gate". From swordsman to kalam expert (pen). Ali was so immersed in it, until then he was 'awakened' again and realized that he had seen so many changes because of the many disputes between his friends that it was difficult to find agreement on various issues. And he realized, it was due to differences in understanding of a problem, coupled with the emergence of hypocrites who began to return to oppose the Islamic government after the death of the Prophet PBUH.

After Uthman died, the community joined in the allegiance of Ali ibn Abi Talib as caliph. However, then there arose a problem when Ali began to issue a new policy as a caliph. Ali deactivated the governors appointed by Uthman. He was convinced that the uprisings were due to their negligence. He also withdrew the land that was given by Uthman to the population by surrendering the proceeds of his income to the state, and re-used the annual tax distribution system among Muslims as had been implemented by Umar. Ali ruled for only six years. During his reign, he faced various upheavals. Ali ibn Abi Talib faced the next problem, namely the rebellion of Talha, Zubair and Aisha. Their reason, they demanded defense of the blood of Uthman who had been shed wrongfully, but Ali did not want to punish the Uthman killers. Ali actually wanted to avoid war. He sent a letter to Talha and Zubair asking the two to negotiate a peaceful settlement of the case.

But the invitation was rejected. Finally, a fierce battle broke out. This war is known as the Jamal War (Camel), because Ayesha in that battle rode a camel, and managed to defeat her opponent. Zubair and Talha were killed, while Ayesha was taken prisoner and sent back to Medina. Ali's policies also led to resistance from the governors in Damascus, Mu'awiyah, who were supported by a number of former high-ranking officials who felt they lost their position and glory. After successfully quelling the Zubair, Talha and Ayesha revolt, Ali moved from Kufa to 
Damascus with a large army. His troops met with the Mu'awiyah forces at Shiffin. A battle took place here known as the Shifiin War. this ended with tahkim (arbitration), but it did not solve the problem, it even led to the emergence of a third group, the khawariz people who came out of Ali's line. As a result, at the end of Ali bin Abi Talib's reign the Muslims were divided into three political forces, namely Mu'awiyah, Shi'a (followers of Abdullah bin Saba 'al-yahudu) who infiltrated Ali's army, and al-Khawarij (people) people who came out of Ali's line). This situation did not benefit Ali.

The emergence of the Khawarij group made the army weaker, while Mu'awiyah's position became stronger. On the 20th of Ramadan $40 \mathrm{H}$ (660 CE), Ali was killed by one of the Khawarij members, Abdullah bin Muljam. D. Leadership Period After Khulafaur Rashidin When the Caliphate period ended, Bakr until Ali was called the Khilafah Rasyidah period. The caliphs were called al-Khulafa 'al-Rashidun, (the caliphs who received instructions). The hallmark of this period is that the caliphs were truly according to the Prophet's example.

Not long after that, Ali ibn Abi Talib faced the revolt of Talha, Zubayr and Aisha. Their reasoning was that Ali did not want to punish the Uthman killers, and they demanded the defense of the blood of Uthman who had been wrongfully shed. Ali actually wanted to avoid war. He sent a letter to Talha and Zubair asking the two to negotiate a peaceful settlement of the case. But the invitation was rejected. Finally, a fierce battle broke out. This war is known as the Jamal War (Camel), because Ayesha in that battle rode a camel, and managed to defeat her opponent. Zubair and Talha were killed while trying to escape, while Ayesha was taken prisoner and sent back to Medina.

At the same time, Ali's policies also led to resistance from the governor in Damascus, Mu'awiyah, who was supported by a number of former high-ranking officials who felt they lost their position and glory. After successfully quelling the Zubair, Talha and Ayesha revolt, Ali moved from Kufa to Damascus with a large army. His troops met with the Mu'awiyah forces at Shiffin. The battle took place here which was known as the Shiffin War. This war ended with tahkim (arbitration), but it did not solve the problem, it even caused the emergence of a third group, al-Khawarij, people who came out of Ali's line.

As a result, at the end of Ali bin Abi Talib's reign the Muslims were divided into three political forces, namely Mu'awiyah, Shi'a (followers) of Ali, and al-Khawarij (people who came out of Ali's ranks). This situation did not benefit Ali. The emergence of al-khawarij group caused the army to weaken, while Mu'awiyah's position became stronger. On the 20th of Ramadan 40 H (660 CE), Ali was killed by one of the Khawarij members, Abdullah bin Muljam. 


\section{Prophetic Leadership Khulafaur Rasyidin}

Caliph Abu Bakr as Shidiq was a figure of leader who firmly and firmly held the truth. Kholifah Abu Bakar as Shidiq immediately membantas a movement that is considered to violate Islam, without giving a chance for the movement to develop.

Caliph Umar bin Khattab was one of the leaders who laid the foundations of Islamic democracy. He really pays attention to and prioritizes the interests of the people. In government he elected officials who were truly trustworthy. Caliph Umar bin Khattab also always opened himself to receive direct votes from his people.

Caliph Usman bin Affan was one of the leaders who was gentle and very concerned about the interests of his people. He prefers to take a persuasive approach if there is turmoil.

Kholifah Ali ibn Abi Talib is a leader who is disciplined, firm, hard in defending the truth. Under certain conditions, Caliph Ali ibn Abi Talib prioritizes the truth he believes, rather than unity. Caliph Ali ibn Abi Talib also highly upheld the decision that had become an agreement.

Because the expansion of the area happened quickly, Umar immediately set up the state administration by copying the administration that had developed, especially in Persia. Government administration is organized into eight provincial regions: Makkah, Medina, Syria, Jazirah Basrah, Kufa, Palestine, and Egypt. Several departments deemed necessary to be established. At the time, the system of payment of salaries and land taxes was arranged and put in order. The court was established in order to separate the judiciary from the executive. To maintain security and order, a police department is formed. Likewise, the public works department. Umar also founded Bait al-Mal, forged currency, and made the Islamic year. Islam, besides being a teaching that regulates human relations with God, is also a religion that is concerned with the formation of society. In the bosom of the Companions, a thick conviction was embedded about the obligation to call the teachings of Islam (da'wah) to all corners of the world. The spirit of da'wah forms a unified unity in the Muslim community.

Byzantium and Persia, the two forces that controlled the Middle East at that time, began to enter a period of decline and weakness, both because of frequent battles between the two and due to problems in their respective countries. Conflict of religious beliefs in the Byzantine region resulted in the loss of religious freedom for the people. The people are not happy because the royal forces impose their adherents. They were also not happy because of the high taxes for the cost of the war against the Persians. Islam came to the areas it entered with a sympathetic and tolerant attitude, not forcing people to change their religion to convert to Islam. The Sami in Syria and Palestine and the Hami in Egypt saw the Arabs closer to them than the Europeans, the Byzantines, who ruled them. 
Egypt, Syria and Iraq are rich regions. This wealth helped Islamic rulers to finance expansion into more remote areas. He also built roads, bridges, mosques and expanded the Prophet's mosque in Medina. After this period, the Islamic government took the form of a kingdom. Power is passed down from generation to generation. In addition, a caliph during the Rashidah caliphate, never acted alone when the state faced difficulties; They always consult with other dignitaries. Leadership which is still very much refers to the leadership of Prophet Muhammad. Because they live with the Prophet and join in the struggle in the name of Islam. If the leadership style is never separated from the signs that have been taught by the Prophet. Although it is increasingly fading, the colors of Islam and the prophets are very thick in the reign of khulafaur rosyidin.

\section{CONCLUSION}

Caliph Abu Bakr as Shidiq was a leader who firmly and firmly held the truth. Can be trusted, have a gentle heart, generous, and loyal to the Prophet Muhammad. Nearly all of his assets were intended for the struggle of Islam. He was the type of leader who carried out almost all the qualities and struggles of the prophets. So the prophetic leader thick in his blood. Abu Bakar followed almost all of the struggles of the prophet Muhammad. So that his behavior in leading the people was not far from the Prophet Muhammad, although there were many trials that came during his time in office.

Caliph Umar bin Khattab was a defender of the Prophet while fighting for Islam. His strength is all for Islam Umar's firmness in dedicating his life to Islam is beyond doubt. Umar began to lay the foundations of Islamic democracy. He really pays attention to and prioritizes the interests of the people. In government he elected officials who were truly trustworthy. Caliph Umar bin Khattab also always opened himself to receive direct votes from his people. Having a heart that is very compassionate to its people, does not want to use state assets for personal use. Almost all of the qualities of the Prophet in leading were carried out by Umar. Courage, obedience, affection, assertiveness, unyielding, using all abilities for the prosperity of the State in many fields.

Caliph Usman bin Affan was a meek leader and heeded the interests of his people. He prefers to take a persuasive approach if there is turmoil. From the beginning before becoming the leader of Muslims he was a companion of the Messenger of Allah, also, so that many patterns of leadership that he did for Muslims. Believe that a rich person is loyal to the struggle of Muslims, loves his people, forgives the guilty. His nature is what later became a boomerang because it is utilized by many interested parties. But all of that is indeed a characteristic of the usman leadership of Muslims. Clearly all can not be separated from the example adopted from the Prophet Muhammad. 
Kholifah Ali ibn Abi Talib is a leader who is disciplined, firm, hard in defending the truth. Under certain conditions, Caliph Ali ibn Abi Talib prioritizes the truth he believes, rather than unity. Caliph Ali ibn Abi Talib also highly upheld the decision that had become an agreement. Ali joined the Prophet Muhammad from childhood. Almost all his life follows the example of the prophet. In terms of daily life in terms of governing and in terms of following the struggle of the Holy Prophet upholding Islam. The protector of the prophet is willing to lay down his life for Islam. The courage to take this risk is a very extraordinary thing to do leaders.

\section{REFERENCES}

Adhanyanto, Oksep. 2011. "Khilafah Dalam Sistem Pemerintahan Islam." Jurnal Ilmu Politik Dan Ilmu Pemerintahan.

Ayief Fathurrahman. 2018. "MEMAHAMI KEBIJAKAN EKONOMI POLITIK TIGA KHALIFAH (Sebuah Kajian Historis Tiga Fase Peradaban Islam).” JES.

Fachrurozi, Moch. 2015. “Trilogi Kepemimpinan Islam: Analisis Teoritik Terhadap Konsep Khilafah, Imamah Dan Imarah." Jurnal Ilmu Dakwah. https://doi.org/10.15575/jid.v4i12.396.

Fitri Sukmawati, Patmawati. 2015. "SEJARAH DAKWAH PADA MASA ABU BAKAR." Al-Hikmah.

Hayat, Al. 2014. "The Return of Khilafah.” Dabiq.

Iwan, Zunaih Ahmad. 2014. "KHILAFAH: SISTEM PEMERINTAHAN YANG PROFAN." Ummul Quro.

Jumat, Abd. Gani. 2014. "KONSEP PEMERINTAHAN DALAM ALQURAN: ANALISIS MAKNA KHALĪFAH DALAM PERSPEKTIF FIQH POLITIK." HUNAFA: Jurnal Studia Islamika.

Nurmala Rahmawati, Sugiyanto, Suranto. 2015. "SISTEM PEMERINTAHAN ISLAM DI BAWAH KEPEMIMPINAN KHALIFAH UTSMAN BIN AFFAN TAHUN 644656." ARTIKEL ILMIAH MAHASISWA.

Radieah, Mohd Nor. 2013. "Pengurusan Baitulmal Era Pemerintahan Khalifah Umar Bin Abdul Aziz." Jurnal Al-Tamadun.

Rahim, Abd. 2012. "Khalīfah Dan Khilafāh Menurut Alquran.” HUNAFA: Jurnal Studia Islamika.

Rahmatullah, Muhammad. 2014. "Kepemimpinan Khalifah Abu Bakar AshShiddiq." Jurnal Khatulistiwa - Journal of Islamic Studies.

Saunders, John Joseph. 2002. A History of Medieval Islam. Routledge.

Susmihara. 2015a. "Khulafa Al-Rasyidin (Dinamika Sosial Politik Dan Dakwah Islam)." Jurnal Adabiyah.

———. 2015b. "KHULAFA AL-RASYIDIN (Dinamika Sosial Politik Dan Dakwah Islam)." Adabiyah.

Yusalia, Henny. 2016. “Dinamika Penerapan Khilafah Sebuah Tinjauan Sosio- 


\section{Edutec}

Journal of Education And Technology

2597-9221 (Online)

Historis Henny Yusalia." Wardah. 